\title{
Assessing the protective efficacy of antibodies to the HIV gp41 region by active vaccination
}

\author{
SK Sharma ${ }^{1 *}$, J Pokorski ${ }^{2}$, MG Finn², J Jacqueline ${ }^{1}$, E Rakasz ${ }^{3}$, D Burton ${ }^{1}$, R Wyatt ${ }^{1}$ \\ From AIDS Vaccine 2012 \\ Boston, MA, USA. 9-12 September 2012
}

\section{Background}

The gp41 cluster I is a conserved immunodominant loop connecting the heptad repeat 1 (HR 1) and heptad repeat 2 (HR2) of the HIV-1 the envelope glycoproteins (Env). Following HIV-1 infection or vaccination with gp41-containing Env immunogens, this region elicits relatively high titers of antibodies generally considered to be non-neutralizing in nature. However, in a recent passive immunization study using a cluster 1 antibody, partial protection against SHIV SF162 P4 challenge was observed. In the present study, we sought to determine if vaccine-elicited cluster 1 antibodies might afford some protective capacity by active vaccination, presumably by binding to non-functional spikes on the virus and slowing the viral entry process in vivo.

\section{Methods}

To generate cluster 1-specific antibodies, we added residues flanking the cluster I cysteine-loop region to allow it to assume its preferred structural conformation. The resultant 20 residues peptides were expressed on the genetically modified Q-beta bacteriophage particles and also chemically coupled to KLH. Sera from rabbits immunized with these antigens were analyzed by ELISA for the binding to cluster 1 peptides and by cross-competition with the known cluster I antibodies.

\section{Results}

The cluster I region was found to be immunogenic and, interestingly, a version of the epitope in which alanines were substituted in place of the small cysteine-linked loop was found to be more immunogenic than the wild-type cysteine-cysteine motif. The sera from rabbits inoculated with either carrier cross-competed with the known cluster I antibodies such as F240. Though the sera did not

${ }^{1}$ International AIDS Vaccine Initiative, La Jolla, CA, USA

Full list of author information is available at the end of the article neutralize JR-FL viruses, they serum antibodies were able to capture many different viruses in vitro.

\section{Conclusion}

We conclude that we have specifically elicited antibodies directed to the cluster 1 region of gp41 possessing properties similar to the known monoclonal antibodies. Active immunization of non-human primates by both the intranasal and intramuscular routes, followed by SHIV.

\section{Author details}

${ }^{1}$ International AIDS Vaccine Initiative, La Jolla, CA, USA. ${ }^{2}$ The Scripps Research Institute, La Jolla, CA, USA. ${ }^{3}$ Wisconsin National Primate Research Center, Univ. of Wisconsin-Madison, WI, USA.

Published: 13 September 2012

\section{doi:10.1186/1742-4690-9-S2-P37}

Cite this article as: Sharma et al:: Assessing the protective efficacy of antibodies to the HIV gp41 region by active vaccination. Retrovirology 2012 9(Suppl 2):P37.

Submit your next manuscript to BioMed Central and take full advantage of:

- Convenient online submission

- Thorough peer review

- No space constraints or color figure charges

- Immediate publication on acceptance

- Inclusion in PubMed, CAS, Scopus and Google Scholar

- Research which is freely available for redistribution 